\title{
Gender Reading and Reader Response Theory
}

By

\author{
Amal Hassanein Sarhan Abu Saif
}

Teaching Assistant at the Department of English, Faculty of Arts

\begin{abstract}
This paper is dedicated to scrutinize the reader response theory and its criticism. Previous research tackling reading strategies of gender is discussed to see how gender influences reading and the different reading strategies of males and females.

The findings are concluded in the fact that female readers ${ }^{6}$ reading strategies highly influence their enjoyment of the genre. The analysis yielded the results that the female reader tends to react emotionally to characters, therefore, they usually identify with the detective. Moreover, her sharp ability of inference and paying attention to hidden messages in texts makes her expect the solutions of mysteries. Consequently, the female reader has a sense of accomplishment.
\end{abstract}

Keywords: Reader Response, gender, reading.

Theorizing about the audience; how it receives something, how to grab its attention and how to incite a particular reaction, has distant roots in criticism. In The Return of the Reader: Reader-Response Criticism (2003), Elizabeth Freund stated that: "an overwhelming but suppressed or rarely acknowledged concern with the reader was at the heart of the New Critical project (42)." Among the early attempts to direct attention to the reader was M.H. Abram's attempt to depict all the elements involved with any work of art in The Mirror and the Lamp: Romantic Theory and the Critical Tradition. For Abram, they are the universe, the work of art, the artist and the audience (6).

According to Abrams, all literary theories study one of the four elements surrounding the work of art. They can study the work itself; which is the main focus of objective theories, or they can study the relationship between the work of art and the artist which is the focus of expressive theories. However, if the theory studies the relationship between the work of art and the surrounding universe, this makes it a mimetic theory. And if it studies the relationship between the work and the audience; this makes it a pragmatic theory. Moreover, theories of reading are divided into those that give the reader complete autonomy 


\section{Amal Hassanein Sarhan Abu Saif}

and power and others that contend that reading is an integrated process in which both the text and the reader work together in order to come up with meaning; Wolfgang Iser is a defender of the second theory.

In The Implied Reader Patterns of Communication in Prose Fiction from Bunyan to Beckette, Iser introduces the artistic and the esthetic poles in order to explain how the realization of the literary work falls between the two of them. He refers to the text by the artistic pole and to the reader's realization the esthetic pole. He explains that the literary work falls half-way between the artistic and the esthetic poles.

Iser suggests that in order for reading to be entertaining, it has to invite the reader to use his imagination and be creative. Consequently, he suggests that the literary work has to be "conceived in such a way that it will engage the reader's imagination in the task of working things out for himself, for reading is only a pleasure when it is active and creative" (275). Therefore, by bringing imagination and creativity to the field, Iser gives the reader power in the reading process, the reader is no longer a passive receptor, he cannot be, because that would abort the concept of the pleasure of reading itself.

Iser suggests that a text is composed of written and unwritten aspects. The unwritten aspects and the "unspoken dialogue," which Iser then calls the "text gaps," constitute the heart of Iser's theory. He explains that text gaps help engage the reader's imagination into action. Iser suggests that the written part of the text controls the implications of the unwritten aspect. Thus, Iser argues that the written aspect of the text imposes certain limits on the unwritten aspect, so that the reader would use his imagination to fill in gaps only according to what the text permits.

Although Iser endorses text gaps with the ability of making possible the text-reader interaction, he adds that "negation" influences that process as well. Negation, for Iser, invokes the reader's set of "determinate elements or knowledge only to cancel them out." However, what the text invokes and cancels remains in the reader's mind and "thus brings about modifications in the reader's attitude toward what is familiar or determinate" (The Reader in the Text Essays on Audience and Interpretation 111-112). Therefore, for Iser, there are two aspects of the text that initiate, influence and control the interaction between the text and the reader. Those aspects are: the text gaps and negation, both of which carries out its role differently. 
While Jane P. Tompkins argues that Iser's theory does not give the reader autonomy in constituting meaning. Instead she views the reader's role in Iser's theory a means of discovering what is "already on this page" (Reader Response Criticism xv). However, her position against Iser's theory might be debatable. For Iser's theory, revolves around that the text and the reader must work together to constitute meaning. If the reader has complete autonomy in constituting meaning, he might constitute non-existent meaning. Therefore, despite the fact that Iser's theory does not give the reader complete freedom, it does not give the text the complete power either.

Stanely Fish's theory is related to Iser's in that it places importance on the reader and his experience, for him, meaning is constituted through the participation of the reader. In "Literature in the Reader: Affective Stylistics," Fish explains that the sentence is not an object in itself; rather, it is an "event, something that happens to, and with the participation of, the reader." Thus, meaning is constituted with the participation of the reader according to what happens to him during that event (New Literary History 125).

Fish's theory suggests that the meaning of a sentence (paragraph, novel, poem) has no direct relationship with what the separate words mean. To put it another way, he argues that the meaning of a word or an utterance might contribute something to its meaning; however, for him what constitutes meaning is the reader's experience of the utterance ("Literature in the Reader" 131). Therefore, Fish explains that sentence takes complete shape and meaning after the reader responds, thus, it is the reader's response that is constituent of the meaning.

Tompkins comments on Fish's theory saying that the fact that meaning is constituted or not constituted only in the reader's mind, not in the text or gaps in the text, entails separation between the reader and the text, and thus, relocates the importance of the reader to the center of critical attention (xvii).

Literary theorists used to believe that one text incites the same response from all the readers, however, psychoanalysts found that every reader responds differently to the text based on different aspects of the reader's personality and experience. Norman Holland believed that the interaction between the text and the reader forces a re-creation of the 
Amal Hassanein Sarhan Abu Saif reader's identity as well as a re-creation of the text's meaning and significance by means of a "transactive" relation between them. Thus, Holland argues that the significance of a text can be determined according to the reader's identity-structure as well as his values and prejudices (Newton 142). Therefore, Holland explains that the text can influence changes to the reader's identity in the same way that the reader's identity gives meaning to the text. In "Unity Identity Text Self," Holland suggests that every reader interprets the text according to his/her own identity. He argues that interpretation, like any other aspect of life, is based upon the reader's experience and his/her way of "coping" (119). Thus, each reader would see in a literary work what concerns him/her; which subsequent theories proved.

David Bleich's emphasis the subjectivity of the reading process is highly related to Holland's theory. By subjectivity Bleich means that every reader is solely responsible for making sense of the text. In Readings and feelings an Introduction to Subjective Criticism he explains that by simply reading the text, it becomes subject to change according to the reader's subjectivity. Bleich argues that the subjective re-creation of a literary text can be realized through the prose presentation of a poem. He suggests that the prose presentation would show the "subjective perception" of the reader and indicate their differences (21). It could be seen that Bleich's theory is related to Holland's idea of how the reader's identity can impose changes to the literary text and that every reader sees and responds to what he thinks is important.

In the study of reader responses, Bleich could identify two different kinds of responses: the affective and the associative responses. Bleich explains and differentiates between the two of them. He explains that in the affective response, the reader "describes the actual affect he felt while reading the poem" (33). Therefore, for Bleich, the affective response is mainly based on the reader's feelings the text aroused in the reader. In that kind of response the reader only describes what he felt moment by moment and the emotional effects of the text.

On the other hand, Bleich explains that the associative response is the most informative kind of responses. It gives a way to express the reader's feelings, preoccupations, perceptions and anything that the reader might have brought to the text to reflect on it, or anything the text extracted from the reader. The associative response shows the personality 
Gender Reading and Reader Response Theory

workings in interpreting the literary text. And this kind of response helps show how each reader's identity structure would affect how he/she responds to a literary text and why their responses could be different.

In the light of the previous discussion, it could be seen that what all the theorists agree on is that meaning resides in the mind of the reader; he interacts with the text, uses his imagination, fills in gaps and brings his personality and identity to the text he reads and makes subjective judgments. In brief, it could be said that for reader-oriented and reader-response theorists, the reader is the one who makes meaning.

\section{Gender and Reading}

New reader-oriented theories started to add another level of studying the reader and his/her communication with the text. Theorists began with the assumption that gender must influence the reading process in some way; that men and women must read things differently. Although this assumption might seem far-fetched to many people, increasing research has shown that it can be true. In "The Reader's Construction of Meaning: Cognitive Research on Gender and Comprehension," Mary Crawford and Roger Chaffin indicate that based on people's sex-role identification, men and women interpret the same words differently. By sex-role identification they mean how much the person identifies with and accepts the role the society has assigned to $\mathrm{him} /$ her depending on his/her gender. They hypothesize that the degree of sex-role identification influences the way people sort out information in memory, consequently, they suppose that the degree of sex-role identification influences the way people read texts and interpret words (Gender and Reading: Essays on Readers, Texts, and Contexts 4).

They build their Schema theory on the notion that "the simplest understanding and recollection depend on knowledge that the reader brings to the task" (4), they call this knowledge the "schema." They hypothesize that there is a gender schema that is learned early in life and that shapes the way men and women interact with the universe and shapes their viewpoints (20).

Their Schema theory to a large extent echoes Iser's theory of the text gaps that the reader fills. They only add that the gender schema fills the gaps differently based on the reader's gender and sex-role identification. As long as every person has his/her own schema which 


\section{Amal Hassanein Sarhan Abu Saif}

helps fill in the gaps in the text, the result would be a unique reading experience for each reader.

Crawford and Chaffin then attempt to explain how the gender schema is formed. They say that individuals develop gender identity early in life, and then they develop certain degree of identification with the sex-role the society and culture associate with his/her gender. Individuals are given a "gender-label" at birth, then they develop a "gender identity," through which they recognize themselves as males or females. From their birth and throughout their childhood, individuals are always exposed to "prescriptions and proscriptions consistent with that label and identity" according to which they start to view and evaluate themselves which they refer to as sex-typing or gender-typing (13).

Crawford and Chaffin hypothesize that "Gender and gendertyping are among the most powerful influences channeling the experiences of individuals." Subsequently, they suppose that gender and gender-typing influence the reading experience in very much the same way they influence everything else in the individual's life. Moreover, they suggest that "Gender and degree of gender-typing affect memory, comprehension, and even grammatical choices, presumably by influencing the availability of the gender schema" (19).

Crawford and Chaffin, however, maintain that men and women do not generate radically different responses. Instead, they said that the differences are subtle (21). They relate this fact to the idea that "women learn to read and understand from men's point of view" (21); the hypothesis suggested by the muted group theory. This theory suggests that this situation occurs when there are imbalanced power relationships between different groups of people. In this situation, the "muted group" learns to use the dominant group's language "in order to be heard" even at the expense of losing some meaning (21).

Elaine Showalter in her essay "Women and Literary Curriculum" shows how female students might learn how to conform to the male's point of view of life as she reads literature. She says that over the course of studying American literature, female students read narratives like The Young Man in American Literature: The Initiation Theme, The Black Man and the Promise of America or Portrait of the Artist as a Young Man. Showalter says that, this way, by the end of the semester, the 
Gender Reading and Reader Response Theory

female students would have learnt "intellectual neutrality; she would be learning, in fact, how to think like a man" (College English 855).

Thus, in response to neutralizing female intellect, Patrocinio P. Schweickart in her essay "Reading Ourselves: toward a Feminist Theory of Reading" suggests that a feminist reading entails "taking control of one's reactions and inclinations" (50). In her viewpoint, a feminist rereading should be considered "a kind of therapeutic analysis." In this therapeutic analysis, a female reader would read a text and consider how she would normally respond to a male text in her neutralized thinking, and then she should "undermine the subjective predispositions that had rendered her vulnerable to its designs." Schweickart refers to the phenomenon of neutralizing the female's intellect the "immasculation" of females' thinking which needs "collective remedy" (Gender and Reading: Essays on Readers, Texts, and Contexts 51).

David Bleich in "Gender Interests in Reading and Language," suggests that there are gender-related differences in the cognitive processes based on the fact that the brain structures differ from men to women. He emphasizes that different "hormone balances" must affect all the biological, lingual and cognitive processes (Gender and Reading: Essays on Readers, Texts, and Contexts 234-235). To examine this hypothesis, Bleich asked his students to give their reflections on different narratives. His analysis of the students' reflections yielded that female and male students paid attention to (saw) different things in the narrative. For example, the female students inferred from the story that the protagonist was seeking vengeance, and related that to some sort of psychological obsession though vengeance was not stated out clearly in the story. However, the male students were not able to see the protagonist's aim for vengeance. Bleich comments that vengeance, mafia stories, police drama and other sorts of violent and tough narrative are culturally considered masculine. Consequently, we might assume that male students would see "vengeance" in the story, however, male students could not infer the act of vengeance from the story they read. His theory is that men can be more literal in their readings, as long as the text does not state the information clearly; men are less likely to infer something from the story and express it. On the other hand, women have greater freedom when it comes to inferring things form narratives. They inferred the protagonist's aim for vengeance as well as his mental health 


\section{Amal Hassanein Sarhan Abu Saif}

status (258). He argues that men are more concerned about accuracy that they "inhibit themselves from saying things that may not be literally documented." On the other hand, he found that inference is more regularly coupled with women's identity that they "achieve certainty about this particular inference much sooner than men do" (258-259).

Therefore, if Holland's theory that the reader brings his/her identity to the task and only sees what matters to him/her would be applied here, it could be said that there is some kind of collective identity of men and women. That collective identity enabled the female students to infer and express things that were not announced clearly in the narrative, while blocked the male students' ability to do so. Notably, this collective identity could be traced back to Crawford's and Chaffin's gender schema; the schema that individuals gather from their birth onwards and which helps them fill in gaps in texts.

Moreover, Bleich suggests that women infer feelings better and faster than men do. He builds his observation on his analysis of people's reflections on the story of "Barn Burning." He says that both men and women gave most of their attention to Sarty, the protagonist; however, there was a difference in the kind of attention given to him. The story begins by describing Sarty's reaction to the cheese smell in the courtroom. One man only reflected that the boy who was waiting for the trial smelled cheese; the other reflected that the boy's nose caught a cheese smell. Both responses, however, when compared to the woman's response who reflected that the boy must have been hungry that he paid attention to the smell, show how men infer feelings better than men do (258-259).

Closely related to and integral with Bleich's conclusion is Elizabeth A. Flynn's theory. Not only this, but also Flynn's theory might prove Bleich's hypothesis. In "Gender and Reading" she argues that men tend to distance themselves from the text during the reading process. To do so, they need to comprehend the text, the failure of which is very disturbing for men. Women, on the other hand, do not care very much about distancing themselves from the text. Instead, women tend to indulge themselves in the text which results in the fact that most women develop affective responses to texts. Consequently, it could be said that comprehension is not considered an urgent need for women. By contrast, 
Gender Reading and Reader Response Theory

men often interrupted their reflections of the stories to say that the text was ambiguous in this part of the story (261).

Thus, as could be seen from Flynn's suggestions, her theory validates Crawford's and Chaffin's hypothesis of the gender schema. She suggests that there is a gender identity that individuals develop early in life and which is influenced by the psychological relationship with the parents. This gender identity helps develop a gender interest and influence the way men and women read texts. Similarly Crawford and Chaffin suggest that the gender identity and gender-typing influence the way individuals interact with the world and shape their viewpoints.

Moreover, Flynn differentiates between what she calls the "dominant pole" and the "submissive pole" of reading. She explains that "the dominant pole is characterized by detachment, observation from a distance. The reader imposes a previously established structure on the text and in so doing silences it" (268). On the other hand, the submissive pole is characterized by "too much involvement. The reader is entangled in the events of the story and is unable to step back, to observe with a critical eye" (267). She noted that men's responses showed a "pattern of dominance" towards the texts. However this pattern was absent in the women's responses to the story. However, she says that women were more able to see feelings and tensions in the stories (272). Therefore, it could be concluded that Bleich theory that men make inferences about feelings better than men do is valid. Additionally, Flynn noted that male students who dominated the text did not empathize with the characters and so detached themselves from the text. Subsequently, male students did not engage emotionally with the text and judged the characters from their dominant pole. One male student rejected the whole text, and by doing so, he dominated the text (273).

Therefore, Flynn detected a link between dominating the text and emotional detachment. She says that male students for instance did not engage emotionally with the protagonist, and therefore, put his experience at a safe distance. This detachment is instantiated through the male students' reference to the protagonist as "little guy" or "some guy's fantasy." Hence, Flynn suggests that if the protagonist is simply a "little guy" and his experience is simply "some guy's fantasy," then his whole experience is insignificant and "the conflict described in the story need not be taken seriously" (273). In this way, men dominate the text. 


\section{Amal Hassanein Sarhan Abu Saif}

Women in Flynn's sample on the other hand were more able to achieve a balance between detachment and emotional engagement. Although they could see the character's limitations, they considered his experience significant. They engaged emotionally with the text, and thus, rendered themselves to the text. Thus, Flynn indicates that women's responses were submissive in the sense that they indulged themselves emotionally with the text (276). Flynn adds that men and women showed the same pattern of responses of different stories. Men tended to dominate the text through emotional detachment while women were submissive in their responses as a result of emotional entanglement, although they could resolve tensions better than men did. Therefore, generally men were closer to the extremes of either domination or submission. Women, however, were "closer to the interactive center" (276).

Some modern empirical studies tried to examine Flynn's conclusions regarding how gender might affect reading. Among these studies is Erik van Schooten et al's "Dimensions and Predictors of Literary Response." The results showed that girls have higher scores on second-order factors as well as on "Leisure Escape, Insight, Empathy, Imagery [and] Vividness." Additionally, they found that girls have lower scores on "Rejecting Literary Values." These results accord with Flynn's hypothesis and conclusion. Moreover, the study found that girls who have higher socioeconomic background pay more attention to literary themes and hidden messages in texts better than men do (JLR 18-19).

Though the study "Gender and Emotional Engagement during Reading," aimed to prove that men and women are similar in the way they read and react to texts and literature, Özen Odağ noticed that there are differences in what men and women choose to focus on during reading as well as, correspondingly, in their responses. Odağ's close analysis of men and women's responses to literature yielded that men focus on feelings of suspense and surprise. Their attention is given to the plot. Odağ calls men's kind of reading the "plot-driven" reading. By contrast, Odağ found that women focus on single characters, identify with them and sympathize with them. This kind of reading he calls the "character-driven reading."

Odağ also noticed that it cannot be said that men do not respond emotionally at all to literary texts. Instead he suggests that men's 
Gender Reading and Reader Response Theory

emotional reactions are different from women's. He argues that men's emotional reactions are based on the plot as a whole not on single characters. For instance he says that women have "a greater sensitivity ... for prosocial and powerless emotions (such as fear, shame, and guilt), in contrast to a more pronounced display of powerful emotions (such as contempt) by men." Thus, men's emotional engagement, for Odağ, is more "in control" because they respond to the plot. However, he finds that women's emotional engagement is "more interpersonal and powerless." Odağ adds that by analyzing the narrative's development without surrendering to the emotional engagement with characters, men were more able to enjoy the narratives "despite the tragic fates" of the characters compared to women. Women on the other hand surrender to the emotional engagement with characters and feel pity and shame for them (Cognition and Emotion 869).

Feng-ming Chi in "Reader Stance and a Focus on Gender Differences" studied the differences between female and male readers as they read texts. First of all, he found that men and women adopted different strategies to talk about parts they did not fully understand. Women said that they did not understand, however, they tried to provide explanations to the parts they did not understand. Men, on the other hand, stated that they did not understand that part and shut down the whole experience, they "disengaged from the text" (English Language Teaching 88). This finding is compatible with Flynn's when she came to the conclusion that men care more about accuracy that they try not to add interpretations that they are not sure about.

Additionally, Chi found that when it comes to the "evaluative stance," men and women also showed different responses. He argues that both men and women displayed emotional reactions; however, they reacted emotionally to different things. For instance, women reacted emotionally to the characters' experiences. On the contrary, men's emotional reaction was directed to the experiences themselves not the characters. This finding replicates Odağ's conclusion that men do engage emotionally with the text but with different aspects of it (English Language Teaching 88).

To sum up, theorists, thinkers and critics all agreed on the fact that the reader participates in making meaning and interacts with the text in different ways. Other thinkers gave the study of the differences 


\section{Amal Hassanein Sarhan Abu Saif}

between men's and women's reading their attention. They came to the conclusion that there are salient differences in the way men and women read and interpret things which proves that they read, understand and interact with texts differently. 
Gender Reading and Reader Response Theory

\section{Works Cited}

Abrams, Meyer H. The Mirror and the Lamp: Romantic Theory and the Critical Tradition. Oxford University Press, 1953.

Bleich, David. Readings and Feelings: an Introduction to Subjective Criticism. National Council of Teachers of English, 1975.

---. "Gender Interests in Reading and Language." Gender and Reading: Essays on Readers, Texts, and Contexts. Hopkins Univ. Press, 1992.

Chi, Feng-Ming. "Reader Stance and a Focus on Gender Differences." English Language Teaching, vol. 2, no. 4, pp. 82-90. 2009.

Crawford, Mary and Roger Chaffin. "The Reader's Construction of Meaning: Cognitive Research on Gender and Comprehension." Gender and Reading: Essays on Readers, Texts, and Contexts. Hopkins Univ. Press, 1992.

Fish, Stanley. "Literature in the Reader: Affective Stylistics." New Literary History, vol. 2, no. 1, 1970, p. 123., doi:10.2307/468593.

Flynn, Elizabeth A. Editor. Gender and Reading Essays on Readers, Texts, and Contexts. Hopkins Univ. Press, 1992.

---. "Gender and Reading." Gender and Reading Essays on Readers, Texts, and Contexts. Hopkins Univ. Press, 1992.

Freund, Elizabeth. The Return of the Reader: Reader-Response Criticism. Routledge, 2003.

Gadamer, H. G. Truth and Method. Translated by Joel G. Weinsheimer and Donald undefined Marshall, Continuum, 2004.

Holland, Norman. "Unity Identity Text Self." Reader Response Criticism from Formalism to Post-Structuralism. Baltimore: The Johns Hopkins University Press, 1980.

Iser, Wolfgang. "Interaction between Text and Reader." The Reader in the Text Essays on Audience and Interpretation. Susan Rubin Suleiman. Editor. Princeton University Press. Pp. 106-119. 2014. 
Amal Hassanein Sarhan Abu Saif

---. The Implied Reader Patterns of Communication in Prose Fiction from Bunyan to Beckette. Johns Hopkins University Press. 1974

Newton, K. M. Twentieth-Century Literary Theory: a Reader. Macmillan, 1997.

Odağ, Özen. "Emotional engagement during literary reception: Do men and women differ?" Cognition and Emotion, 27:5, 856-874. Routledge. 2013.

Schooten, Erik Van, et al. "Dimensions and Predictors of Literary Response." Journal of Literacy Research, vol. 33, no. 1, 2001, pp. 132., doi:10.1080/10862960109548101.

Schweickart, Patrocinio P. "Reading Ourselves: toward a Feminist Theory of Reading." Gender and Reading: Essays on Readers, Texts, and Contexts. Hopkins Univ. Press, 1992.

Showalter, Elaine. "Women and the Literary Curriculum." College English, vol. 32, no. 8 , 1971, p. 855., doi:10.2307/375623.

Tompkins, Jane P. Ed. Reader-Response Criticism: From Formalism to PostStructuralism Baltimore: The Johns Hopkins University Press, 1980.

---. "An introduction to reader response criticism." Reader-Response Criticism: From Formalism to Post-Structuralism. Baltimore: The Johns Hopkins University Press, 1980.

Wu, Chiu-Yen and Chi-Shiou Lin. "The Pleasures of Reading Mystery Fiction and Mystery Readers' Book Selection Behavior." Journal of Educational Media \& Library Sciences 53:3 pp. 361:388.(2016) 